\title{
CORRECTION
}

View Article Online

View Journal I View Issue

CrossMark
\&lickfor updates
Cite this: J. Mater. Chem. A, 2015, 3,
9317

DOI: $10.1039 / c 5 t a 90073 e$

www.rsc.org/MaterialsA

\section{Correction: Structure and function relationships in alkylammonium lead(II) iodide solar cells}

\author{
Majid Safdari, ${ }^{a}$ Andreas Fischer, ${ }^{a}$ Bo Xu, ${ }^{\text {b Lars Kloo }}{ }^{a}$ and James M. Gardner ${ }^{\star a}$ \\ Correction for 'Structure and function relationships in alkylammonium lead(॥) iodide solar cells' by Majid \\ Safdari et al., J. Mater. Chem. A, 2015, DOI: 10.1039/c4ta06174h.
}

A row from Table 3, and a phrase from the caption, were not included in the manuscript. The correct Table 3 is shown below.

Table 3 Photovoltaic parameters (average values of 5 devices) of the $\mathrm{MAPbI}_{3}, \mathrm{EAPbI}_{3}$ and $\mathrm{PAPbI}_{3}$ devices. $600 \mathrm{~nm}$ thick $\mathrm{TiO}_{2}$ films were used as substrate, and Spiro-OMeTAD was used as the HTM. A $200 \mathrm{~nm}$ layer of silver was used as back contact. Conductivity data collected as described in the text.

\begin{tabular}{|c|c|c|c|}
\hline & $\mathrm{MAPbI}_{3}$ & $\mathrm{EAPbI}_{3}$ & $\mathrm{PAPbI}_{3}$ \\
\hline$J_{\mathrm{sc}} \mathrm{mA} \mathrm{cm}^{-2}$ & $16.29 \pm 1.69$ & $0.77 \pm 0.14$ & $0.075 \pm 0.021$ \\
\hline$V_{\mathrm{oc}}(\mathrm{V})$ & $0.784 \pm 0.026$ & $0.662 \pm 0.040$ & $0.564 \pm 0.034$ \\
\hline FF & $0.580 \pm 0.011$ & $0.521 \pm 0.051$ & $0.372 \pm 0.034$ \\
\hline$\eta(\%)$ & $7.4 \pm 0.59$ & $0.26 \pm 0.025$ & $0.016 \pm 0.004$ \\
\hline APCE & 78.35 & 2.83 & 0.18 \\
\hline Band gap (eV) & 1.6 & 2.2 & 2.4 \\
\hline Conductivity $\left(\mathrm{S} \mathrm{cm}^{-1}\right)$ & $1.1 \times 10^{-4}$ & $1.3 \times 10^{-6}$ & $9.4 \times 10^{-7}$ \\
\hline
\end{tabular}

The Royal Society of Chemistry apologises for these errors and any consequent inconvenience to authors and readers. 